\title{
Dynamics of clinical-neurological indicators of patients with hemorrhagic hemispheric stroke in the recovering period of the disease
}

\author{
S. O. Miedviedkova ${ }^{\star A, E, F}$, A. O. Dronova ${ }^{\mathrm{B}, \mathrm{C}, \mathrm{D}}$
}

Zaporizhzhia State Medical University, Ukraine

A - research concept and design; B - collection and/or assembly of data; C - data analysis and interpretation; D - writing the article; $\mathrm{E}$ - critical revision of the article; $\mathrm{F}$ - final approval of the article

Key words: hemorrhagic stroke, rehabilitation, recovery period.

Pathologia 2021; 18 (1), 96-102

*E-mail: s.medvedkova@ gmail.com
The aim of our study was the investigation of the dynamics of clinical-neurological indicators of patients with hemorrhagic hemispheric stroke (HHS) in the recovering period of the disease by comprehensive neurological, medical and social research.

Materials and methods. 90 patients in the age from 38 to 70 years were studied, 58 men $-64.4 \%$ and 32 women $-35.6 \%$. The condition of the patients was evaluated by NIHSS, mRS, BI and MSA on the $30^{\text {th }}, 180^{\text {th }}, 360^{\text {th }}$ day of HHS. Depending on their self-care recovering level the patients were divided in two groups for analysis: the first one was formed with the patients whose self-care level completely was restored on the $360^{\text {th }}$ day $(\mathrm{BI}=100)$, and the second one was formed with the patients with $\mathrm{BI} 95$ and less on the $360^{\text {th }}$ day.

Results. Structure of indicators according to NIHSS, mRS, BI and MSA on the $30^{\text {th }}$ day of disease in these groups was analyzed during rehabilitation, as well as distribution of the patients based on their gender and process lateralization. Analyzing the data of the dynamics of the recovery period of HHS depending on the lateralization of the process and the sex of patients, we can notice that there was no significant difference during the recovery period of HHS depending of the lateralization of the process, for example, in patients with the damaged dominant hemisphere median score of $\mathrm{BI}$ was 70 points on the $30^{\text {th }}$ day, patients with the lesion of subdominant hemisphere -65 , and on the $360^{\text {th }}$ days in both groups it was 95 points. There was also no significant difference in the dynamics of neurological deficit and recovery of functional activity depending on the gender of patients. On the $30^{\text {th }}$ day of the disease in the group of patients who fully restored their daily activity on the $360^{\text {th }}$ day of HHS a significantly higher score for $\mathrm{BI}$ was determined than in the group with incomplete recovery $(80(70 ; 85)$ points against $55(45 ; 65)$ points $(P<0.05))$. Although a significantly greater regression of functional disorders was found in the second group of patients $(P<0.05)$. An analysis of the impact of spasticity on the recovery of self-care level showed a significant negative impact of increased muscle tone on the recovery of self-care $(P<0.05)$ and reduction of the probability of complete recovery of independence in everyday life with increasing degree of spasticity $(P<0.05)$. At the same time, no significant factors (sex, age, side of the lesion, etc.) were identified that would affect the development of spasticity in patients with HHS, except for the level of neurological deficit according to NIHSS. When we analyzed the distribution of patients in these two groups by sex, it was revealed that the groups didn't have any significant difference. There was also no significant difference in the study's groups depending of the lateralization of the stroke.

Conclusions. It was found that on the $30^{\text {th }}$ day of the disease in $35.6 \%$ of patients the total score on NIHSS ranged from 2 to 6 points, $55.6 \%$ of patients had $\mathrm{mRS}$ of 3 points and $48.9 \%$ of patients had severe dependent of outside help in daily life by BI. Significant positive dynamics of recovery on NIHSS, $\mathrm{mRS}, \mathrm{BI}$ scales on the $180^{\text {th }}$ and $360^{\text {th }}$ day of the disease $(P<0.05)$ was revealed. The dependence of the indicators of the level of self-care on the $360^{\text {th }}$ day of HHS, on the severity of stroke on the $30^{\text {th }}$ day of the disease $(P<0.01)$ and on the presence of manifestations of increased muscle tone was established. It was found that patients who had manifestations of spasticity on the $360^{\text {th }}$ day of the disease had a significantly higher score for NIHSS at the onset of the disease, on the $30^{\text {th }}$ day of the disease and on the $360^{\text {th }}$ day of the disease than patients without manifestations of increased muscle tone $(P<0.05)$. However, no interconnection was found between the indicators of the level of self-care on the $360^{\text {th }}$ day of HHS and the lateralization of the process as well as the sex of patients.
Киючові слова: геморагічний інсульт, реабімітація, відновний період.

Патологія. 2021. T. 18, № 1(51).

C. $96-102$

\section{Аинаміка киініко-неврологічних показників у хворих на геморагічний півкульовий інсульт у відновному періоді захворювання}

\section{С. О. Медвєакова, А. О. Аронова}

Мета роботи - виявлення динаміки клініко-неврологічних показників у хворих на геморагічний півкульовий інсульт (ГПІ) у відновному періоді шляхом комплексного неврологічного та медико-соціального дослідження.

Матеріали та методи. Обстежили 90 хворих віком 38-70 років: 58 (64,4%) чоловіків і 32 (35,6 \%) жінки. Стан пацієнтів оцінили за NIHSS, mRS, BI та MSA на 30, 180, 360 добу ГПІ. Залежно від відновлення рівня самообслуговування пацієнтів поділили на дві групи: в першу ввійшли пацієнти, в яких на 360 добу визначили повне відновлення рівня самообслуговування (BI = 100), у другу групу - пацієнти, в яких на 360 добу $\mathrm{BI} \leq 95$.

Результати. Аналізуючи дані хворих під час реабілітації, не встановили вірогідної різниці перебігу відновного періоду ГПІ залежно від латералізації процесу. Так, наприклад, у пацієнтів з ураженням домінантної півкулі медіана сумарного бала за ВI на 30 добу захворювання становила 70 балів, у пацієнтів з ураженням субдомінантної півкулі - 65, а на 360 добу в обох групах - 95 балів. Також не виявили вірогідної різниці в динаміці неврологічного дефіциту та відновлення функціональної активності залежно від статі хворих. На 30 добу захворювання у групі пацієнтів, які повністю відновили свою повсякденну активність на 360 добу ГПІ, визначили достовірно вищий бал за ВІ, ніж у групі з неповним відновленням $(80(70 ; 85)$ балів проти $55(45 ; 65)(p<0,05))$. Хоча встановили вірогідно більший регрес фрункціональних 
порушень у другій групі спостереження ( $<<0,05)$. Проаналізували вплив проявів спастичності на відновлення рівня самообслуговування; встановили вірогідний негативний вплив наявності підвищеного м'язового тонусу на відновлення рівня самообслуговування $(p<0,05)$ і зниження вірогідності повного відновлення незалежності в повсякденному житті при зростанні ступеня проявів спастичності ( $<<0,05)$. Водночас не виявили вірогідні фрактори (стать, вік, бік ураження тощо), які б впливали на розвиток спастичності в пацієнтів із ГПІ, крім рівня неврологічного дефіциту за NIHSS.

Висновки. Встановили, що на 30 добу захворювання у 35,6 \% пацієнтів сумарний бал за NIHSS дорівнював 2-6, за mRS 55,6 \% пацієнтів мали 3 бали, в 48,9 \% пацієнтів виявлена помірна залежність від сторонньої допомоги за BI. Визначили вірогідну позитивну динаміку відновлення показників за шкалами NIHSS, mRS, BI на 180 і 360 добу захворювання $(p<0,05)$. Встановили залежність показників рівня самообслуговування на 360 добу ГПІ від тяжкості інсульту на 30 добу захворювання ( $p<0,01)$ і від наявності проявів підвищеного м'язового тонусу. Виявили, що хворі, які мали прояви спастичності на 360 добу захворювання, мали вірогідно вищий бал за NIHSS у дебюті, на 30 та 360 добу захворювання, ніж хворі без проявів підвищеного м'язового тонусу $(p<0,05)$. Водночас не виявили взаємозв'язок між показниками рівня самообслуговування на 360 добу ГПІ і латералізації процесу, а також статтю пацієнтів.

\section{Аинамика клинико-неврологических показателей у больных геморрагическим полушарным инсультом в восстановительном периоде заболевания}

\section{С. А. Медведкова, А. А. Аронова}

Цель работы - определение динамики клинико-неврологических показателей у больных с геморрагическим полушарным инсультом (ГПИ) в восстановительном периоде путем комплексного неврологического и медико-социального исследования.

Материалы и методы. Обследовали 90 больных в возрасте от 38 до 70 лет: 58 (64,4 \%) мужчин и 32 (35,6 \%) женщины. Состояние пациентов оценивали по NIHSS, mRS, BI и MSA на 30, 180, 360 сутки ГПИ. В зависимости от восстановления уровня самообслуживания пациентов поделили на две группы: в первую вошли пациенты, у которых на 360 сутки отмечено полное восстановление уровня самообслуживания (BI = 100), а во вторую группу -пациенты с ВІ на 360 сутки 95 и меньше.

Результаты. Анализируя данные пациентов во время проведения реабилитации, не установили достоверную разницу течения восстановительного периода ГПИ в зависимости от латерализации процесса. Так, например, у пациентов с поражением доминантного полушария медиана суммарного балла по ВI на 30 сутки заболевания была 70 баллов, у пациентов с поражением субдоминантного полушария - 65, а на 360 сутки в обеих группах - 95 баллов. Также не отмечена достоверная разница в динамике неврологического дефицита и восстановления фуункциональной активности в зависимости от пола больных. На 30 сутки заболевания в группе пациентов, которые полностью восстановили свою повседневную активность на 360 сутки ГПИ, установлен достоверно высший балл по ВІ, чем в группе с неполным восстановлением $(80(70 ; 85)$ баллов против $55(45 ; 65)(p<0,05))$. Хотя определен достоверно больший регресс функциональных нарушений во второй группе наблюдения $(p<0,05)$. Проведен анализ влияния проявлений спастичности на восстановление уровня самообслуживания, который показал достоверное негативное влияние наличия повышенного мышечного тонуса на восстановление уровня самообслуживания $(p<0,05)$ и снижение вероятности полного восстановления независимости в повседневной жизни при росте степени проявлений спастичности $(p<0,05)$. Не установлены достоверные факторы (пол, возраст, сторона поражения и т. п.), которые влияли бы на развитие спастичности у пациентов с ГПИ, кроме уровня неврологического дефицита по NIHSS.

Выводы. На 30 сутки заболевания у 35,6 \% пациентов суммарный балл по NIHSS составлял 2-6, по mRS 55,6 \% пациентов имели 3 балла, у 48,9 \% пациентов отмечена умеренная зависимость от посторонней помощи по ВI. Отмечена достоверная положительная динамика восстановления показателей по шкалам NIHSS, mRS, BI на 180 и 360 сутки заболевания ( $<<0,05)$. Установлена зависимость показателей уровня самообслуживания на 360 сутки ГПИ от тяжести инсульта на 30 сутки заболевания $(p<0,01)$ и от наличия проявлений повышенного мышечного тонуса. Установлено, что больные, которые имели проявления спастичности на 360 сутки заболевания, имели достоверно более высокой балл по NIHSS в дебюте, на 30 и 360 сутки заболевания, чем больные без проявлений повышенного мышечного тонуса $(p<0,05)$. При этом не обнаружена взаимосвязь между показателями уровня самообслуживания на 360 сутки ГПИ и латерализации процесса, а также полом пациентов.

Cerebrovascular diseases occupy one of the leading positions in terms of prevalence, disability and mortality in the world as well as in Ukraine [1]. According to the scientists, the number of strokes in the world is growing annually by $0.5-2.0 \% .5 .9$ million people die from stroke per year for today [2]. According to experts, the number of deaths from strokes will increase to 7.8 million per year by 2030 .

Indicators of disability of patients with hemorrhagic stroke after one year in Ukraine is from 75 to $85 \%$. Most patients after stroke have difficulty performing routine daily works, which determines their functional dependence on outside help [2,3]. About 20-30\% of stroke patients need outside help for the rest of their lives [3-5].

Despite the great share of resources aimed for rehabilitation measures in patients who have a stroke, active research in this area has been observed only in the last ten years $[6,7]$ and in general focuses on cases of ischemic etiology. In addition, more guidelines on rehabilitation measures have a purely empirical basis and have no evidence base $[6,8]$.

Hemorrhagic stroke is an acute disturbance of cerebral circulation due to hemorrhage into the substance of the brain, under the arachnoid, or a combination of
Ключевые слова: геморрагический инсульт, реабилитация, восстановительный периол.

Патология. 2021

T. 18, № 1(51).

C. $96-102$ 
hemorrhage into the substance and under the membranes of the brain. Hemorrhagic stroke is the most dangerous form of all cerebrovascular disorders in terms of severity, degree of disability and mortality. It affects more younger people than ischemic stroke $[3,9]$. Therefore, the rehabilitation, restoration of functional activity and return of patients to their social activity is extremely actual problem for doctors and scientists.

\section{Aim}

To investigate the dynamics of clinical-neurological indicators of patients with hemorrhagic hemispheric stroke in the recovering period of the disease by comprehensive neurological, medical and social research.

\section{Materials and methods}

Open, cohort observation of 90 patients with hemorrhagic hemispheric stroke (HHS) in the recovery period of the disease was performed in the clinic of nervous diseases of ZSMU. There were 58 men $(64.4 \%)$ and 32 women $(35.6 \%)$. The average age of patients was $55.59 \pm 10.11$ years.

Clinical neurological examination was carried out according to the special developed protocol including the usage of modern scales, mainly: objectification of the severity of patients was performed on the stroke scale of the National Institute of Health Stroke Scale (NIHSS), assessment of the degree of functional recovery and disability on the modified Rankin Scale (Modified Rankin Scale - mRS), assessment of skills and self-care were examined using the Barthel ADL Index (BI), the presence and severity of spastic manifestations in the muscles of the upper and lower extremities (Modified Ashworth Scale (MAS)) on the $30^{\text {th }}, 180^{\text {th }}, 360^{\text {th }}$ day of HHS. At the same time, a favorable functional outcome for $\mathrm{mRS}$ was considered a score of 1 and 2 points, relatively favorable -3 points, and unfavorable -4 points. During the assessment for $\mathrm{BI}$ - complete independence in self-care corresponded to a score of 100 points, mild dependence - 90-95 points, moderate dependence 65-85 points, severe dependence on outside help 25-60 points.

The presence of hemorrhagic hemispheric stroke in patients was confirmed by computed tomography (CT) examination in the acute period of the disease. All patients on the first day of the disease were consulted by neurosurgeons as for the solution concerning surgical treatment of HHS. According to the results of consultations, conservative treatment was recommended for all studied patients.

The statistical analysis was carried out in the Statistica 13.0 (StatSoft Inc., № JPZ804I382130ARCN10-J) using descriptive statistics methods. The interrelation between qualitative features was evaluated according to the criterion of Pearson Chi square test. The interrelation was considered significant at the level of significance $P<0.05$. The significance of the difference between quantitative features was assessed using the Mann-Whitney U-test.

The study did not include patients with recurrent strokes, patients with two or more lesions, as well as patients with cancer, alcohol abuse, somatic pathology in a state of decompensation, which is a contraindication for active rehabilitation, as well as in the presence of history of traumatic brain injury.

All patients got three courses of complex rehabilitation treatment in specialized department (the duration of one course of treatment is 21 days) during first year after $\mathrm{HHS}$ that included following methods in accordance with standards and protocols for the assistance to patients with hemorrhagic stroke (The Order of the Ministry of Health of Ukraine No. 275 dated 05/17/2014):

- Drug treatment: pathogenetic drugs (antihypertensives, drugs that improve coronary blood flow and metabolism in the heart muscle, antiarrhythmic (if necessary, for patients with ischemic heart disease), antidiabetic (if necessary, for patients with diabetes mellitus 2 type)); drugs that increase metabolism and microcirculation in brain tissues; symptomatic drugs (muscle relaxants, analgesics, neuro-psychotropic drugs, etc.).

- Therapeutic physical training: positional treatment, individual workout, coaching in correct gait, mechanotherapy with the use of table simulators for hands and fingers, special means to reduce muscle tone.

-Physiotherapy: massage of segmental areas, paretic limbs, etc., equipment physiotherapy (electrophoresis, electrostimulation, magnetic therapy, etc.).

- Psychotherapy: autogenic training, psychogymnastics.

- Speech therapy correction, classes with a speech therapist-aphasiologist.

- Other special treatments.

A lot of attention in the early recovery period of patients with HHS was paid not to drugs recovery, but to therapeutic exercise, massage, hardware physiotherapy.

During the development of the rehabilitation program, generally-accepted terms $[6,10]$ were kept, which were also worked out and updated by us.

Following general physiological grounded principles were used:

1. Individual approach to the patient. In the process of developing a rehabilitation program, it is necessary to take into consideration age, sex and profession of the patient, his motor experience, the nature and extent of the pathological process and the functionality of the patient.

2. Consciousness. Only conscious and active participation of the patient himself in the rehabilitation process creates the necessary psycho-emotional background and psychological adjustment of the rehabilitated patient, thereby increasing the effectiveness of the applied rehabilitation measures.

3. The principle of graduality is especially important in increasing physical activity according to all its indicators: volume, intensity, number of exercises, number of their repetitions, complexity of exercises both within one lesson and throughout the whole rehabilitation process.

4. Regularity - the basis of medical and rehabilitation training during the rehabilitation process, which sometimes lasts up to several months and even years. Only according to systematic using of various means of rehabilitation, we can provide sufficient, optimal influence for each patient, which allows to increase the functional state of the patient's body. 
5. Cyclicity. Alternation of work and rest following an optimum interval (rest both between two exercises and between two sessions). If the next session is for the supercompensation phase, the effects of training are summed up and functional possibilities are increased to a new, more advanced level.

6. Systematic impact (or sequence), namely the sequential alternation of starting positions and exercises for different muscle groups.

7. Novelty and diversity as for selection and application of exercises, in another words $10-15 \%$ of exercise should be updated, and 85-90\% repeated to consolidate the success of treatment.

8. Moderation of influence by physical rehabilitation measures means: physical activity should be moderate, possibly longer, or the load should be fractional, which will allow the patient to achieve the adequacy of the load.

In addition, creating individual methods of performing physical rehabilitation and massage, the following items were taken into account:

1) an integrated approach in assessing the patient's condition, considering the characteristics of the disease;

2) mandatory consideration of the pathogenetic and clinical characteristics of the disease, as well as the age and fitness of the patient:

3) outlining of therapeutic tasks as for an individual patient or group of patients;

4) systematization of special exercises that have an aimed impact on the functions of the affected organ;

5) a rational combination of special exercises with tonics to ensure both general and special load.

In accordance with the periods of HHS (acute, early recovery, late recovery and residual) during physical rehabilitation, the following periods are also distinguished: the first (sparing) period, during which $75 \%$ of general and breathing exercises and only $25 \%$ of special exercises are performed, using mostly slow pace; the second (functional) period, which is aimed at restoring the function of the affected organ, when the patient already has a more advanced motor regime, and his general condition is stable; the third (training) period, when not only the restoration of the functionally affected organ is carried out, but the whole organism as well.

Techniques and intensity of physical activity and the number of additional procedures for patients changed during the recovery period of GPI treatment according to general condition, hemodynamic indexes of patients and changes in clinical symptoms (manifestations of spasticity, etc.).

Among the treated patients there were 47 patients $(52.22 \%)$ who had manifestations of mild spasticity $(31.11 \%)$ or moderate and severe ones $(21.11 \%)$. For this group of patients, in addition to the course of physical rehabilitation, special exercises were used to reduce muscle tone, massage techniques, which were aimed at muscle relaxation and treatment of posture (according to the indications).

During training session all the patients performed exercises in order to increase the strength of paretic muscles, but patients with manifestations of muscle spasticity had a number of peculiarities: firstly, muscle strengthening was carried out in the range of small amplitudes, and only then expanded to full (physiological) volume; the alternation of the contraction of spastic muscles with their subsequent stretching to physiological length was obligatory; the necessity of an early transition from abstract exercises to exercises that are household skills, the stopping of training with increasing muscle tone. Also, the general principle was the reproduction and formation of the most important motor skills (skills of getting out of bed, proper gait, sitting, eating, etc.), which was conducted among all patients.

The following exercises were actively used to reduce muscle tone during physical therapy classes in patients with manifestations of spasticity:

- performance of passive movements in separate and adjacent joints, where the main task was the performance of movement in the same direction and plane with a speed that will not cause an increase in muscle tone (such movements lead to the reproduction of adequate patient proprioceptive information in paretic limbs to further ensure active motor acts);

- directed tension of antagonist muscles (at the same time choose the position in which the spastic muscles are maximally relaxed);

- obtaining minimal, dosed movements in spastically contracted muscles with their subsequent gradual decrease or increase, which allows the patient to learn to control the state of spastically tense muscles.

In all patients with HHS, physical therapy classes were conducted under constant control of blood pressure (BP), as well as ECG and level of glucose if necessary, and in case of its deviations, classes or procedures were stopped, in some cases it was necessary to reduce both training time and duration of the massage on a regular basis, but not to lose their effectiveness due to the possibility of increasing the frequency of training. Also, in patients with $\mathrm{HHS}$, the percentage of strength exercises and exercises with isometric muscle tension was reduced (to avoid sharp rises in blood pressure).

During the massage in patients with spastic muscle tension, preference was given to relaxation techniques (stroking, large shaking, very slow kneading) with the impact on segmental and reflex points. Special attention was paid to ensure that muscle tone does not rise above baseline.

\section{Results}

The onset of the disease was acute in all observed patients, in 83 cases - up to one hour (92.2\%), and in $7(7.8 \%)$ - the symptoms increased within 1-3 hours. 71 patients $(78.9 \%)$ were delivered to the department of acute cerebrovascular disorders at the onset of the disease within 6 hours, $15(16.7 \%)$ - sought to help within 24 hours from the disease onset, and only 4 patients (4.4\%) - hospitalized more than a day after the first symptoms of HHS. 16 patients (17.8 \%) had a disturbance of consciousness at the beginning of the disease.

Hypertension was the etiological factor of HHS in all the examined patients. In addition, some patients had comorbid pathology - ischemic heart disease (7 cases, $7.8 \%$ ) and diabetes mellitus type 2 (4 cases, $4.4 \%)$. Treatment of comorbid diseases was carried 
Table 1. Dynamics of NIHSS, mRS and BI in patients with HHS on the $30^{\text {th }}, 180^{\text {th }}$ and $360^{\text {th }}$ day of the disease

\begin{tabular}{ll|l|l|l} 
& & The $30^{\text {th }}$ day & The $180^{\text {th }}$ day & The $360^{\text {th }}$ day \\
NIHSS & Me $\left(Q_{25} ; Q_{75}\right)$ & $8(5 ; 10)$ & $6(4 ; 8)$ & $5(3 ; 7)$ \\
& Up to 6 points, $n(\%)$ & $32(35.6)$ & $53(58.9)$ & $66(73.3)$ \\
& $7-9$ points, $n(\%)$ & $28(31.1)$ & $31(34.4)$ & $21(23.3)$ \\
& 10 or more points, $\mathrm{n}(\%)$ & $30(33.3)$ & $6(6.7)$ & $3(3.4)$ \\
mRS & Me $\left(Q_{25} ; Q_{75}\right)$ & $3(2 ; 3)$ & $2(2 ; 3)$ & $2(2 ; 2)$ \\
& $1, n(\%)$ & - & $9(10.0)$ & $16(17.8)$ \\
& $2, n(\%)$ & $25(27.8)$ & $45(50.0)$ & $53(58.9)$ \\
& $3, n(\%)$ & $50(55.5)$ & $35(38.9)$ & $21(23.3)$ \\
BI & $4, n(\%)$ & $15(16.7)$ & $1(1.1)$ & - \\
& Me $\left(Q_{25} ; Q_{75}\right)$ & $70(60 ; 85)$ & $90(85 ; 95)$ & $95(90 ; 100)$ \\
& $40-60$ points, $n(\%)$ & $32(35.5)$ & - & - \\
& $65-85$ points, $\mathrm{n}(\%)$ & $44(48.9)$ & $41(45.6)$ & $14(15.6)$ \\
& $90-95$ points, $\mathrm{n}(\%)$ & $8(8.9)$ & $32(35.5)$ & $36(40 / 0)$ \\
& 100 points, $\mathrm{n}(\%)$ & $6(6.7)$ & $17(18.9)$ & $40(44.4)$ \\
\hline
\end{tabular}

Table 2. Dynamics of NIHSS indexes in patients with HHS depending on the manifestations of spasticity on the $360^{\text {th }}$ day of the disease, $\operatorname{Me}\left(Q_{25} ; Q_{75}\right)$

\begin{tabular}{|c|c|c|c|}
\hline & \begin{tabular}{|l|} 
NIHSS \\
in debut
\end{tabular} & $\begin{array}{l}\text { NIHSS } \\
\text { on the } 30^{\text {th }} \text { day }\end{array}$ & $\begin{array}{l}\text { NIHSS } \\
\text { on the } 360^{\text {th }} \text { day }\end{array}$ \\
\hline $\begin{array}{l}\text { Manifestations of spasticity are } \\
\text { absent }\end{array}$ & $8(6 ; 12)$ & $6(4 ; 8)$ & $4(2 ; 5)$ \\
\hline Mild spasticity & $11(10 ; 13)^{1}$ & $9(7.75 ; 10.00)^{2}$ & $5(4.00 ; 6.25)^{1}$ \\
\hline $\begin{array}{l}\text { Spasticity of moderate and severe } \\
\text { degree }\end{array}$ & $14(11 ; 15)^{3,4}$ & $10(8.5 ; 11.5)^{4}$ & $7(6 ; 7)^{3,4}$ \\
\hline
\end{tabular}

1: $P<0.05$ between patients with absent manifestations of spasticity and patients with mild spasticity 2: $\mathrm{P}<0.01$ between patients with absent manifestations of spasticity and patients with mild spasticity;

3: $P<0.05$ between patients with mild spasticity and patients with moderate and severe spasticity; 4: $\mathrm{P}<0.01$ between patients with absent manifestations of spasticity and patients with moderate and severe spasticity.

Table 3. Dynamics of NIHSS and mRS in patients with HHS depending on the level of self-care recovery $\mathrm{Me}(\mathrm{Q} 25 ; \mathrm{Q} 75)$

\begin{tabular}{|c|c|c|c|c|c|c|}
\hline & \multicolumn{3}{|l|}{ NIHSS } & \multicolumn{3}{|l|}{ mRS } \\
\hline & $\begin{array}{l}\text { The } 30^{\text {th }} \\
\text { day }\end{array}$ & $\begin{array}{l}\text { The } 180^{\text {th }} \\
\text { day }\end{array}$ & $\begin{array}{l}\text { The } 360^{\text {th }} \\
\text { day }\end{array}$ & $\begin{array}{l}\text { The } 30^{\text {th }} \\
\text { day }\end{array}$ & $\begin{array}{l}\text { The } 180^{\text {th }} \\
\text { day }\end{array}$ & $\begin{array}{l}\text { The } 360^{\text {th }} \\
\text { day }\end{array}$ \\
\hline $\mathrm{BI}=100$ & $\begin{array}{l}6.0 \\
(2.0 ; 6.0)\end{array}$ & $\begin{array}{l}5.0 \\
(3.5 ; 6.0)\end{array}$ & $\begin{array}{l}3.0 \\
(2.5 ; 4.5)\end{array}$ & $\begin{array}{l}3.0 \\
(2.0 ; 3.0)\end{array}$ & $\begin{array}{l}2.0 \\
(2.0 ; 2.0)\end{array}$ & $\begin{array}{l}2.0 \\
(1.0 ; 2.0)\end{array}$ \\
\hline $\mathrm{Bl} \leq 95$ & $\begin{array}{l}9.0 \\
(7.0 ; 11.0)^{1}\end{array}$ & $\begin{array}{l}7.0 \\
(6.0 ; 8.0)^{1}\end{array}$ & $\begin{array}{l}6.0 \\
(5.0 ; 7.0)^{1}\end{array}$ & $\begin{array}{l}3.0 \\
(3.0 ; 4.0)^{1}\end{array}$ & $\begin{array}{l}3.0 \\
(2.0 ; 3.0)\end{array}$ & $\begin{array}{l}2.0 \\
(2.0 ; 3.0)^{1}\end{array}$ \\
\hline
\end{tabular}

1. $\mathrm{P}<0.05$ between patients with $\mathrm{BI}=100$ on the $360^{\text {th }}$ day and patients with $\mathrm{BI} \leq 95$ on the $360^{\text {th }}$ day.

out according to the prescriptions of a cardiologist and an endocrinologist.

In most amount of cases (88.9\%) HHS developed against the background of elevated blood pressure (BP) (160-230/100-130 mm Hg), and only in $10.7 \%$ cases - patients had normal values of BP. At the same time, 48 patients $(53.5 \%)$ reported that they knew about the presence of disease (hypertension) and didn't take the recommended antihypertensive therapy or took it only if they had hypertensive crises.

In 78 patients (86.7\%), apart from focal symptoms in the form of hemiparesis of varying severity and speech disorders (in the case of dominant hemisphere lesion), there were complaints of headache, which in 50 patients $(55.5 \%)$ preceded the development of focal symptoms.

CT examination of the brain in 39 cases (43.3\%) revealed the parenchymal hemorrhage without break- through into the ventricular system and subarachnoid space, in $16(17.8 \%)$ - with breakthrough of blood into the ventricular system, in $12(13.3 \%)$ had a breakthrough in the subarachnoid space, and another 23 patients $(25.6 \%)$ had a breakthrough in both the subarachnoid and ventricular space.

The dynamics of NIHSS, $\mathrm{mRS}$ and $\mathrm{BI}$ in patients with HHS on the $30^{\text {th }}, 180^{\text {th }}$ and $360^{\text {th }}$ day of the disease are shown in Table 1.

In $43(47.8 \%)$ patients on the $30^{\text {th }}$ day of the disease there were no manifestations of increased muscle tone of the central type in the affected limbs, in 30 (33.3\%) patients there were manifestations of mild spasticity according to MAS, in 17 (18.9\%) - of moderate degree. In $43(47.8 \%)$ patients on the $360^{\text {th }}$ day of the disease there were no signs of increased muscle tone, in 30 (33.3 \%) patients there were manifestations of mild spasticity according to MAS, in $15(16.7 \%)$ - moderate degree, and in two more patients (2.2 \%) - there was spasticity of an obvious degree.

Patients who showed signs of increased muscle tone on the $360^{\text {th }}$ day of the disease had a significantly higher score for NIHSS at the onset of the disease, on the $30^{\text {th }}$ day of the disease and on the 360th day of the disease than patients without spasticity $(P<0.05)$ (Table 2$)$.

Analyzing the data of the dynamics of the recovery period of HHS depending on the lateralization of the process and the sex of patients, we can notice that there was no significant difference during the recovery period of $\mathrm{HHS}$ depending of the lateralization of the process, for example, in patients with the damaged dominant hemisphere median score of $\mathrm{BI}$ was 70 points on $30^{\text {th }}$ day, patients with the lesion of subdominant hemisphere 65 , and on the $360^{\text {th }}$ day in both groups it was 95 points. There was also no significant difference in the dynamics of neurological deficit and recovery of functional activity depending on the gender of patients.

Patients were divided into two groups for analysis depending on the recovery of the level of self-care on the $360^{\text {th }}$ day: one included patients who had a complete recovery of the level of self-care on the $360^{\text {th }}$ day $(\mathrm{BI}=100)$, and the second group included patients with $\mathrm{BI}$ on the $360^{\text {th }}$ day 95 and less.

It was revealed that patients who fully restored functional activity on the $360^{\text {th }}$ day of the disease had a significantly lower rate of neurological deficit on the $30^{\text {th }}$ day of the disease (for NIHSS - the median total score was $6(1 ; 6)$ points) than patients who had a mild and moderate dependence on outside help (for $\mathrm{BI}<95$ ) on the $360^{\text {th }}$ day, at the end of the first month of the disease (for NIHSS Me $=9(7 ; 11)$ points) $(P<0.01)$.

The dynamics of NIHSS and mRS in patients with HHS depending on the level of recovery of self-care on the $360^{\text {th }}$ day of the disease are shown in Table 3.

As can be seen from Table 3, there was a significant difference in the assessment of the level of disability by $\mathrm{mRS}$ between groups on the $30^{\text {th }}$ day of the disease.

On the $30^{\text {th }}$ day of the disease in the group of patients who fully restored their daily activity on the $360^{\text {th }}$ day of HHS significantly higher score for $\mathrm{BI}$ was determined than in the group with incomplete recovery $(80(70 ; 85)$ points against $55(45 ; 65)$ points $(P<0.05))$. Although a 
significantly greater regression of functional disorders was found in the second group of patients $(P<0.05)$.

We analyzed the structure of indicators for NIHSS, $\mathrm{mRS}$ and $\mathrm{BI}$ on the $30^{\text {th }}$ day of the HHS in the group of patients with $\mathrm{BI}=100$ on the $360^{\text {th }}$ days and $\mathrm{BI}=95$ or less on the $360^{\text {th }}$ day.

Analyzing the group of patients who fully restored activity in daily life on the $360^{\text {th }}$ day, there were $8.7 \%$ of cases from them who had a total NIHSS score 10 or more on the $30^{\text {th }}$ day of the disease, and $69.6 \%$ of cases had a total score for NIHSS 6 and less.

Moreover, the structure of both groups on the $30^{\text {th }}$ day was also determined according to the degree of functional recovery and disability according to the modified Rankin scale and the degree of functional activity.

An analysis of the impact of spasticity on the recovery of self-care level showed a significant negative impact of increased muscle tone on the recovery of self-care $(\mathrm{P}<0.05)$ and reduction the probability of complete recovery of independence in everyday life with increasing degree of spasticity $(P<0.05)$ (Table 4).

At the same time, no significant factors (sex, age, side of the lesion, etc.) were identified that would affect the development of spasticity in patients with HHS, except for the level of neurological deficit according to NIHSS.

When we analyzed the distribution of patients in these two groups by sex, it was revealed that the groups didn't have any significant difference. There was also no significant difference in the study groups depending of the lateralization of the stroke.

\section{Discussion}

In recent years, the issue of rehabilitation of post-stroke patients has been actively studied. And more often the authors do not focus on the rehabilitation of patients with hemorrhagic stroke, and more often it is about the rehabilitation of patients who have suffered an ischemic stroke. There is also an active search for factors that affect the effectiveness of rehabilitation measures. French scientists (Broussy S. and his colleagues) emphasize that today the issue of long-term rehabilitation of patients with stroke is a serious problem of the modern health care system, although we still know little about the recovery process and factors influencing the effectiveness rehabilitation in patients with stroke. That is why there is an urgent need to study them [11].

The greater efficiency of rehabilitation in the conditions of a specialized inpatient department [12] was proved and it was demonstrated that to a large extent the effectiveness of rehabilitation measures depended on the functional state of patients at the beginning of the disease $[13,14]$. This was demonstrated in our study too, namely from the level of neurological deficit according to NIHSS $(P<0.01)$. Also, at the same time, researchers from Korea Chang W.H. and other authors did not evaluate such a factor as the presence and severity of spasticity to restore the level of patient self-care, which was carried out in our work. We have shown that the presence of $\mathrm{HHS}$ in the recovery period of increased muscle tone in the central type reduced the likelihood of complete recovery of self-care and affected dependence on outside
Table 4. Distribution of patients by manifestations of increased muscle tone in groups with $\mathrm{BI}=100$ and $\mathrm{BI} \leq 95$ on the $360^{\text {th }}$ day

\begin{tabular}{l|lll|l|l} 
& \multicolumn{3}{|l|}{ BI $=\mathbf{1 0 0}$} & \multicolumn{3}{l}{ BI $\leq 95$} \\
& n & \% & n & \% \\
\hline Manifestations of spasticity are absent & 25 & 28.9 & 18 & 20.0 \\
\hline Mild spasticity & 14 & 14.4 & 16 & 17.8 \\
\hline Spasticity of moderate and severe degree & 1 & 1.1 & 16 & $17.8^{1}$ \\
\hline
\end{tabular}

1: $P<0.05$.

help, which is certainly an important medical, social and economic aspect of rehabilitation of post-stroke patients.

Researchers from Italy (Zucchella C. and others) conducted an investigation to study the course of the recovery period in patients older than 65 years, and the influence of age on indicators, including functional recovery. It was shown that the age of the patients influences the course of the rehabilitation process, but the age after which there was a decrease in the effectiveness of rehabilitation was determined to be 85 years [15]. These data were also confirmed in the study by Korean scientists $[14,16]$. In our study we did not find a significant difference in the recovery period from the age of patients, which is most likely due to the fact that our sample included patients under the age of 85 (this indicator was undoubtedly influenced by average life expectancy in Ukraine, which is much less than in Italy).

\section{Conclusions}

As a result of the study, we made the following conclusions:

1. It was found that on the $30^{\text {th }}$ day of the disease in $35.6 \%$ of patients the total score on NIHSS ranged from 2 to 6 points, $55.6 \%$ of patients had $\mathrm{mRS}$ of 3 points and $48.9 \%$ of patients had severe dependence on outside help in daily life by BI. Significant positive dynamics of recovery by NIHSS, $\mathrm{mRS}, \mathrm{BI}$ scales on the $180^{\text {th }}$ and $360^{\text {th }}$ day of the disease $(P<0.05)$ was revealed.

2. The dependence of the indicators of the level of self-care on the $360^{\text {th }}$ day of HHS, on the severity of stroke on the $30^{\text {th }}$ day of the disease $(P<0.01)$ and on the presence of manifestations of increased muscle tone was established.

3. It was found that patients who had manifestations of spasticity on the $360^{\text {th }}$ day of the disease had significantly higher score for NIHSS at the onset of the disease, on the $30^{\text {th }}$ day of the disease and on the $360^{\text {th }}$ day of the disease than patients without manifestations of increased muscle tone $(P<0.05)$. However, no interconnection was found between the indicators of the level of self-care on the $360^{\text {th }}$ day of HHS and the lateralization of the process as well as the sex of patients.

\section{Funding}

The study is funded as a part of scientific research work in Zaporizhzhia State Medical University “Improving diagnosis and treatment of cerebral circulation disorders at different stages of the disease", number of state registration 0118U007145.

Conflicts of interest: authors have no conflict of interest to declare. Конфмікт інтересів: віАсутній. 
Надійшла Ао реАакції / Received: 27.10.2020

Після Аоопрацювання / Revised: 12.12.2020

Прийнято Ао Аруку / Accepted: 28.12.2020

\section{Information about authors:}

Miedviedkova S. O., MD, PhD, DSc, Professor of the Department of Family Medicine, Therapy, Cardiology and Neurology of the Faculty of Postgraduate Education, Zaporizhzhia State Medical University, Ukraine.

Dronova A. O., MD, PhD Student of the Department of Family Medicine, Therapy, Cardiology and Neurology of the Faculty of Postgraduate Education, Zaporizhzhia State Medical University, Ukraine.

\section{Відомості про авторів:}

МєавєАкова С. О., А-р меА. наук, професор каф. сімейної медицини, терапії, кардіології та неврології ФПО, Запорізький Аержавний медичний університет, Україна.

Аронова А. О., аспірант каф. сімейної медицини, терапії, кардіології та неврології ФПО, Запорізький Аержавний меАичний університет, Україна.

\section{Сведения об авторах:}

Медведкова С. А., А-р меА. наук, профессор каф. семейной меАицины, терапии, карАиологии и неврологии ФПО, Запорожский государственный меАицинский университет, Украина.

Аронова А. А., аспирант каф. семейной медицины, терапии, кардиологии и неврологии ФПО, Запорожский государственный медицинский университет, Украина.

\section{References}

[1] Koziolkin, O. A., Kuznietsov, A. A., \& Novikova, L. V. (2018). Prediction of the functional outcome of acute recurrent cerebral ischemic hemispheric stroke. Pathologia, 15(3), 354-359. https://doi.org/10.14739/2310$\underline{1237.2018 .3 .151859}$

[2] Wang, Y., Li, H., Wei, H., Xu, X., Jin, P., Wang, Z., Zhang, S., \& Yang, L. (2019). Assessment of the quality and content of clinical practice guidelines for post-stroke rehabilitation of aphasia. Medicine, 98(31), e16629. https://doi.org/10.1097/MD.0000000000016629

[3] Mishchenko, T. S. (2017) Epidemiologiya tserebrovaskulyarnykh zabolevanii i organizatsiya pomoshchi bol'nym s mozgovym insul'tom $\checkmark$ Ukraine [Epidemiology of cerebrovascular diseases and organization of medical care for patients with stroke in Ukraine]. Ukrainskyi visnyk psykhonevrolohii, 25(1), 22-24. [in Russian].

[4] Janzen, S., Mirkowski, M., McIntyre, A., Mehta, S., Iruthayarajah, J., \& Teasell, R. (2019). Referral patterns of stroke rehabilitation inpatients to a model system of outpatient services in Ontario, Canada: a 7-year retrospective analysis. BMC health services research, 19(1), 399. https://doi.org/10.1186/s12913-019-4236-5

[5] Koziolkin, O. A., Miedviedkova, S. O., Shevchenko, L. O., Liakhova, I. M., Malakhova, S. M., Lisova, O. O., \& Cherepok, O. O. (2019). Efficiency of medical and physical rehabilitation in patients who suffered from cerebral ischemic stroke. Pathologia(2), 200-206. https://doi. org/10.14739/2310-1237.2019.2.177125

[6] Winstein, C. J., Stein, J., Arena, R., Bates, B., Cherney, L. R., Cramer, S. C., Deruyter, F., Eng, J. J., Fisher, B., Harvey, R. L., Lang, C. E., MacKay-Lyons, M., Ottenbacher, K. J., Pugh, S., Reeves, M. J., Richards, L. G., Stiers, W., Zorowitz, R. D., \& American Heart Association Stroke Council, Council on Cardiovascular and Stroke Nursing, Council on Clinical Cardiology, and Council on Quality of Care and Outcomes Research (2016). Guidelines for Adult Stroke Rehabilitation and Recovery: A Guideline for Healthcare Professionals From the American Heart Association/American Stroke Association. Stroke, 47(6), e98-e169. https://doi.org/10.1161/STR.0000000000000098

[7] Rakesh, N., Boiarsky, D., Athar, A., Hinds, S., \& Stein, J. (2019). Poststroke rehabilitation: Factors predicting discharge to acute versus subacute rehabilitation facilities. Medicine, 98(22), e15934. https://doi. org/10.1097/MD.0000000000015934

[8] Dionísio, A., Duarte, I. C., Patrício, M., \& Castelo-Branco, M. (2018). The Use of Repetitive Transcranial Magnetic Stimulation for Stroke Rehabilitation: A Systematic Review. Journal of stroke and cerebrovascular diseases, 27(1), 1-31. https://doi.org/10.1016/j.jstrokecerebrovasdis.2017.09.008

[9] Edwardson, M. A., Ding, L., Park, C., Lane, C. J., Nelsen, M. A., Wolf, S. L., Winstein, C. J., \& Dromerick, A. W. (2019). Reduced Upper Limb Recovery in Subcortical Stroke Patients With Small Prior Radiographic
Stroke. Frontiers in neurology, 10, 454. https://doi.org/10.3389/ fneur.2019.00454

[10] Epifanov, V. A., \& Epifanov A. V. (2014). Reabilitatsiya $v$ nevrologii [Rehabilitation in neurology]. Moscow. [in Russian].

[11] Broussy, S., Rouanet, F., Lesaine, E., Domecq, S., Kret, M., Maugeais, M., Aly, F., Dehail, P., Bénard, A., Wittwer, J., Salamon, R., Sibon, I., \& Saillour-Glenisson, F. (2019). Post-stroke pathway analysis and link with one year sequelae in a French cohort of stroke patients: the PAPASePA protocol study. BMC health services research, 19(1), 770. https://doi. org/10.1186/s12913-019-4522-2

[12] Gabet, A., de Peretti, C., Woimant, F., Giroud, M., Béjot, Y., Schnitzler, A., \& Olié, V. (2018). Admission in Neurorehabilitation and Association with Functional Outcomes after Stroke in France: ANation-Wide Study, 2010-2014. Journal of stroke and cerebrovascular diseases, 27(12), 3443-3450. https://doi.org/10.1016/j.jstrokecerebrovasdis.2018.08.005

[13] Chang, W. H., Sohn, M. K., Lee, J., Kim, D. Y., Lee, S. G., Shin, Y. I., Oh, G. J., Lee, Y. S., Joo, M. C., Han, E. Y., Kang, C., \& Kim, Y. H. (2016). Predictors of functional level and quality of life at 6 months after a first-ever stroke: the KOSCO study. Journal of neurology, 263(6), 1166-1177. https://doi.org/10.1007/s00415-016-8119-y

[14] Menoux, D., Jousse, M., Quintaine, V., Tlili, L., \& Yelnik, A. P. (2019). Decrease in post-stroke spasticity and shoulder pain prevalence over the last 15 years. Annals of physical and rehabilitation medicine, 62(6), 403-408. https://doi.org/10.1016/j.rehab.2018.03.003

[15] Zucchella, C., Consilvio, M., lacoviello, L., Intiso, D., Tamburin, S., Casale, R., \& Bartolo, M. (2019). Rehabilitation in oldest-old stroke patients: a comparison within over 65 population. European journal of physical and rehabilitation medicine, 55(2), 148-155. https://doi. org/10.23736/S1973-9087.18.05297-8

[16] Ren, L., Wang, K., Shen, H., Xu, Y., Wang, J., \& Chen, R. (2019). Effects of continuous positive airway pressure (CPAP) therapy on neurological and functional rehabilitation in Basal Ganglia Stroke patients with obstructive sleep apnea: A prospective multicenter study. Medicine, 98(28), e16344. https://doi.org/10.1097/MD.0000000000016344 